\title{
Pedagojik Formasyon Eğitimi Alan Öğrencilerin Kendilerinden Kaynaklanan Sorunları ${ }^{1}$
}

DOI: $10.21666 /$ muefd.331972

\author{
Bilgen KIRAL \\ Adnan Menderes Üniversitesi, \\ bilgenkiral@gmail.com
}

$\ddot{O}_{\text {zet }}$

Bu araştırma 2016-2017 akademik yllında Aydın Adnan Menderes Üniversitesinde pedagojik formasyon eğitimi alan 300 gönüllü ögrenci ile gerçekleş̧tirilmiştir. Araştırmada pedagojik formasyon ĕgitimi alan ögrencilerin kendilerinden kaynaklanan sorunlar araştırılmış̧tır. Öğrencilerin sorunları ailevi, maddi, psikolojik, toplumsal ve fizyolojik sorunlar olarak beş temada incelenmiştir. Araştırmada nitel yaklaşım benimsenmiştir. Araştırma sonucunda son sınıf ögrencileri psikolojik sorunları daha fazla yaşarken; mezun ögrencilerin ailevi, maddi, toplumsal ve fizyolojik sorunları daha fazla yaşadıkları tespit edilmiştir. Öğrencilerin yaşamış oldukları psikolojik sorunları çözmek için üniversite bünyesinde verilen danışmanlık hizmetleri yaygınlaştırımalıdır. Ayrıca öğrencilerin sorunlarını en aza indirmek amacıyla kaygı, iletişsim, stres yönetimi vb. konularda seminer gibi hizmetler çoğaltılmalıdır.

Anahtar Kelimeler: Pedagojik formasyon eğitimi, ögrenci, sorun

\section{Pedagogical Formation Training Students' Problems Caused From Themselves}

\begin{abstract}
This research was carried out with 300 volunteer students attending pedagogical formation training at Aydın Adnan Menderes University in 2016-2017 academic year. In the study, the problems of pedagogical formation education students from themselves were researched. The problems of the students were examined in five themes as family, economicl, psychological, social and physiological problems. A qualitative approach was adopted in the research As a result of the research, while the last year students are experiencing more psychological problems; It has been found that the graduated students have more family, economic, social and physiological problems. In order to solve the psychological problems experienced by the students, counseling services provided within the university. In addition, anxiety, communication, stress management etc. seminars have been multiplied in order to minimize the problems of the student.
\end{abstract}

Keywords: Pedagogical formation training, student, problem

Geleceğin şekillendirilmesinde en önemli görev öğretmenlere düşmektedir. Öğretmenler geleceği şekillendirirken, toplumların kültürünü, değerlerini, yapısal özelliklerini de gelecek nesillere aktarmaktadırlar. Yaptıkları kasıtlı kültürlemelerle aslında toplumun devamını sağlamaktadırlar. O zaman öğretmen denilen kişi toplumun en bilgili, en kültürlü, teknolojiyi en etkili şekilde kullanan, en araştırmacı kısacası her açıdan en donanımlı bireyler olmalıdır. Öğretmenlere bu kadar büyük bir yük yüklenmişken, öğretmen yetiştirme sisteminin de tıpkı öğretmenler gibi mükemmel olması gerekmektedir. Tabiî ki öğretmenlerin, öğretmenlik mesleği öncesindeki süreçte bilgi dağarcı̆̆ını genişletmesi, kendisinde var olan becerilere yenilerini eklemesi, her alanda kendisini yetiştirmesi gerekmektedir. Okumayı seven, kendini geliştiren, çevresini her anlamda aydınlatan bireyler öğretmenlik mesleğini yapmalıdır. Öğretmen Tük Dil Kurumunun Sözlüğünde (2016) mesleği bilgi öğretmek olan kişi şeklinde geçmektedir. Cambridge Sözlüğünde de (2016) benzer bir tanım bulunmaktadır. Okulda, kolejde vb. yerlerde işi öğretmek olan kişi şeklinde tanımlanmıştır. Her iki sözlükte geçen bilgi öğretmek ya da öğretim işiyle uğraşmak olan iş bir günde kazanılamaz. Bilgi

\footnotetext{
${ }^{1} \mathrm{Bu}$ araştırma 3-7 Mayıs 2017 tarihlerinde Muğla Sıtkı Koçman Üniversitesi II. Uluslararası Felsefe, Eğitim, Sanat ve Bilim Tarihi Sempozyumu'nda sözlü bildiri olarak sunulmuştur.
} 
birikim işidir ve sarmal bir şekilde çoğalır. Bireyin nitelikli ve bilgili bir öğretmen olmasında kendi yeteneğinin dışında hizmet öncesinde aldığı eğitim de çok önemlidir. Öyleyse burada büyük pay öğretmen yetiştiricilerine düşmektedir. Öğretmen yetiştirme görevini günümüzde eğitim fakülteleri üstlenmiştir. Eğitim fakültelerini bitiren öğrenciler öğretmen lisansı ile mezun olmaktadırlar. Eğitim fakültelerinden mezun olan öğrencilerin dişında pedagojik formasyon adı verilen bir sertifika programı ile üniversitelerin çeşitli fakültelerinden mezun olan öğrenciler de öğretmenlik lisansı elde etmektedirler. Bu fakülteler arasında ilk sırayı fen-edebiyat fakültesi almakta bunu sağlık bilimleri fakültesi, iktisadi-idari bilimler fakültesi, turizm fakültesi, ilahiyat fakültesi gibi fakülteler izlemektedir. Pedagojik formasyon eğitimi alan öğrenciler, lisans öğrenimine devam eden ve/veya lisans mezunu olan öğrencilerdir. Yapılan bu çalışmada öncelikle öğretmenlik mesleğinin tarih içerisindeki gelişimi ve bugünkü durumu ele alınmış, pedagojik formasyon eğitiminin kökenleri incelenmiş, ardından pedagojik formasyon eğitimi alan gelecekte öğretmen olarak eğitim sistemine girme ihtimali olan öğretmen adaylarının pedagojik formasyon eğitimi sırasında kendilerinden kaynaklanan sorunlarının araştırılmasına yer verilmiştir.

\section{Geçmişten Günümüze Öğretmen Yetiştirme Sistemi}

Osmanlı Devletinde Fatih Sultan Mehmet zamanında öğretmenlerin medreselerde yetiştiği görülmüştür. Fatih, Eyüp Sultan ve Ayasofya Medreselerinde sıbyan mekteplerine muallim olacaklar için genel medrese eğitiminden farklı bir program önermiştir. Buna göre medreselerdeki muallim adayları Arapça, adab-1 muhasebe ve usul-i tedris, münakaşalı akaid, mantık, hesap (hendese dersinde), coğrafya (heyet dersinde), tarih (edebiyat dersinde) gibi derslerden sorumluydular. Bu programın iki ilginç yanı olduğu görülmektedir. Adab-1 muhasebe ve usul-i tedris dersi tartışma kuralları ve öğretim yöntemi anlamına gelmektedir. Bu ilkokul öğretmen adayları için hem Türk tarihinde, hem de Dünya tarihinde son derece önemli bir adımdır. İkincisi ise fikıh dersinin öğretmen adayları için uygun bulunmamış olmasıdır. Oysaki medrese öğrencileri fikıh dersi görmekteydiler. Fatih, öğretmen yetiştirme programını, alanın özelliklerine göre ilk kez düzenleyen bir program yapıcı olarak görülmektedir. Fatih’ten sonra öğretmen adayları için uygulanan bu uygulamaya son verilmiş, sıbyan mektebi öğretmenleri medreselerde biraz okumuş ya da kendi kendine okuma öğrenen ağır başlı kişilerden oluşmuştur (Akyüz, 2015; Aydın ve Madden, 2006; Başaran, 1996; Baskan, Yıldırım ve Vural; 2014). 1848 y1lına gelindiğinde ise muallim yetiştirmek amacıyla Darülmuallimin denilen öğretmen okullarının açıldığı görülmektedir (Aycan, 2015; Ayas, 2009; Aydın, 1998; Başaran, 1996; Eşme, 1999; Gurbetoğlu, 2015; Önal, 2015; Şendağ ve Gedik, 2015; Tekış1k, 1987; Uygun, 2010; Yıldırım ve Vural, 2014). Bu gelişme, öğretmen okullarının temelini oluşturmaktadır. İlerleyen yıllarda öğretmen okullarının Darülmuallimin-i Rüşdi (ortaöğretmen okulları), Darülmuallimin-i Sibyan (ilköğretmen okulları), Darülmuallimat (kız öğretmen okulları), Darülmuallimin-i İdadi ve İstanbul Darülmuallimin-i (Öğretmen lisesi ve İstanbul Öğretmen Okulu) gibi farklı adlarla sayılarının arttığı görülmektedir (Akyüz, 2015; Başaran, 1996; Gurbetoğlu, 2015; Önal, 2015; Üstüner, 2004; Y1ldırım ve Vural, 2014; Y1lmaz, 201). Cumhuriyet dönemine (1924-1925 yılından itibaren) gelindiğinde ise Darülmuallimin denilen okulun adı "Muallim Mektebi" olmuş; 1935'lerde ise "Öğretmen Okulu" adını almıştır (Akyüz, 2015; Baskan, Aydın ve Madden, 2006; Üstüner, 2004; Yıldırım ve Vural, 2014).

İlkokul öğretmeni yetiştirme sistemine bakılacak olunursa; 1923'te cumhuriyetin ilanından sonra 10.102 ilkokul öğretmeninin olduğu görülmektedir. Bunların bir kısmı medreselerin alt sınıflarından ayrılmış veya Darülmualliminlerde 1-2 yıl öğrenim gören çoğu imamlık ve müzezzinlikle görevli hocalardı. Ancak bu sayı yeterli olmadığı için cumhuriyet döneminde çalışmalara başlanmıştır. 1924-1925 yıllarında muallim mektepleri 5 yıl öğrenim verirken; 19321933 yılına gelindiğinde bu okulların süresi 6 yıla çıkarılmıştır. İlk üç y1l ortaokul, son üç yıl mesleki devre olarak uygulanmıştır. Bu uygulama 1970-1971'li yıllara kadar devam etmiş, bu yıllardan itibaren lise kısmı 4 yıla çıkarılmıştır (Akyüz, 2015; Baskan, 2001; Uygun, 2010; Üstüner, 2004; Yıldırım ve Vural, 2014; Yılmaz, 2015). Milli Eğitim Bakanı Mustafa Necati zamanında 1926'da Kayseri'de Zincidere Köyü'nde Köy Muallim Mektebi açılmıştır. Bu okul 
köyler için açılan ilk öğretmen okulu olup; 1932'de kapatılmıştır. 1927'de Denizli Erkek Muallim Mektebi Köy Muallim Mektebi'ne çevrilmiş, 1933'te kapatılmıştır. Milli Eğitim Bakanı Saffet Arıkan döneminde 1936'da Eskişehir'in Mahmudiye Köyü'nde bir eğitmen kursu açılmıştır. Askerde onbaşı, çavuşluk yapmış, köylü gençlerin altı aylık bir kurstan sonra eğitmen unvanıyla küçük köylere ve üç yıllık ilkokullara gönderilip öğretmen sıkıntısını hafifletmek amaçlanmıştır. Köy Enstitüleri Milli Eğitim Bakanı Hasan Ali Yücel zamanında köylerdeki eğitim ihtiyacını karşılamak amacıyla 17 Nisan 1940 tarihli 3803 sayılı kanunla kurulmuştur. 1954 yılında ilköğretmen okullarıyla birleşmiştir (Baskan, 2001; Başaran, 1996; Gurbetoğlu, 2015; Uygun, 2010; Üstüner, 2004; Y1ldırım ve Vural, 2014). 1974-1975 öğretim yılından itibaren bazı ilköğretmen okullarında 2 yıllık yüksek okul seviyesinde eğitim enstitüleri oluşturulmuş, eğitim enstitüsü olmayanlar ise öğretmen liselerine dönüştürülerek ilköğretmen okulları tarihe karışmıştır. Eğitim enstitüleri 20 Temmuz 1982'den itibaren Eğitim Yüksek Okulları haline dönüştürülerek, üniversitelerin içine alınmıştır. Eğitim enstitüleri, 1989-1990 öğretim yılında 4 yıla çıkarılmış, Temmuz 1992'de de eğitim fakülteleri haline getirilmiştir (Akyüz, 2015; Baskan, 2001; Baskan, Aydın ve Madden, 2006; Eşme, 1999; Tozlu, 2015).

Ortaokul öğretmeni yetiştirme sistemine bakıldığında; ortaokullara muallim yetiştirmek için Konya'da ilk Muallim Mektebinin açıldığı ve 1 Mart 1927 de öğretime başladığı görülmektedir. Bu okul ilk açıldığında sadece Türkçe bölümü ve 16 öğrenci ile öğretime başlamış; 1927-1928 öğretim yılında Ankara'ya taşınmış ve pedagoji bölümü eklenmiş; 1928' de ilk mezunlarını vermiştir. Milli Eğitim Bakanı Mustafa Necati tarafından yaptırılan Kasım 1929'da bitirilen Gazi Muallim Mektebi ve Terbiye Enstitüsü Cumhuriyet döneminde ilk kurulan öğretmen okullarıdır. 1928-1930 yılları arasında tarih-coğrafya, matematik, fizik ve tabi bilimler adıyla farklı bölümler kurulmuştur. 1932'de resim-iş ve beden eğitimi bölümleri; daha sonraki y1llarda müzik, Fransızca, İngilizce, Almanca vb. gibi farklı bölümler de bu okulun bünyesine eklenmiştir. 1967-1968 yıllarında bu okulun süresi 3 yıla, 1978-1979 yılında ise 4 yıla çıkarılmış ve okulun adı Gazi Yüksek Öğretmen Okulu olarak değiştirilmiştir. Bu kurumlar 20 Temmuz 1982'de eğitim fakültelerine dönüştürülüp üniversitelere bağlanmıştır (Akyüz, 2015; Başaran, 1996; Baskan, 2001; Gurbetoğlu, 2015; Kavcar, 2002; Taneri, 2016; Üstüner, 2004; Yıldırım ve Vural, 2014).

Liselere öğretmen yetiştirme sistemine bakıldığında, 1959 yılına kadar liselere öğretmen yetiştiren kurum İstanbul Yüksek Öğretmen Okulu idi. Bu okulun tek başına yetersiz olması nedeniyle Ankara'da ve İzmir'de de Yüksek Öğretmen Okulları açılmıştır. İlköğretmen okullarının en başarılı ve kişilikli öğrencileri arasından seçilenler bu okullarda öğrenim görmekteydiler. Bu okullar da 20 Temmuz 1982'de eğitim fakültelerine dönüştürülmüşlerdir. Ayrıca 1959'da İstanbul'da bir Yüksek İslam Enstitüsü açılmış olup, ilerleyen yıllarda sayıları 7'yi bulmuştur. Bu okullarda imam hatip okullarına meslek dersi ve orta dereceli okullara din dersi öğretmeni yetiştirmek amaçlanmıştır. 4 Kasım 1997 yılında Yüksek Öğretim Kurulu (YÖK) eğitim fakültelerinde yeniden yapılanmaya gitmiştir. Eğitim fakültelerinde bölüm bazında uygun bölümler açılması, ortaöğretim için sosyal, fen ve matematik öğretmenlerinin tezsiz yüksek lisans düzeyinde yetiştirilmesi gibi çalışmalar yapılmıştır (Akyüz, 2015; Argün, 2008; Aycan, 2015; Başaran, 1996; Kavcar, 2002; Taneri, 2016; Uygun, 2010; Üstüner, 2004).

Teknik eğitime bakılacak olursa; 1930'lu yıllarda teknik eğitim alanında öğretmen yetiştirme alanıyla ilgili herhangi bir çalışma yapılmadığı görülmektedir. 1934'te Kız Teknik Yüksek Öğretmen Okulu açılmış, başlangıçta 3 yıl olup, 1948'de öğrenim süresi 4 yıla çıkarılmıştır. Bu kurum Kız Sanat Enstitüleri'ne öğretmen yetiştirmiştir. Daha sonra akşam kız sanat okullarına öğretmen yetiştiren 2 yıllık okullar açılmıştır. Okul öncesi eğitimine de bu okullarda ön lisans eğitimi ile öğretmen yetiştirilmiştir. 1973'te ise Ankara'da erkek sanat enstitülerine öğretmen yetiştiren Erkek Teknik Yüksek Öğretmen Okulu açılmıştır. Ayrıca pratik sanat okullarına öğretmen yetiştiren iki yıllık okullar da hizmet vermeye başlamıştır. Mesleki ve teknik alanlara öğretmen yetiştiren okullar 20 Temmuz 1982'de üniversite çatısı altında fakülteye dönüştürülmüştür (Başaran, 1996).

Yukarıda belirtilen öğretmen yetiştirme sistemlerinin dişında "yedek subay öğretmenler, vekil öğretmenler, barış gönüllüleri, mektupla öğretmen yetiştirme, hızlandırılmış programla öğretmen 
yetiştirme, öğretmenlik formasyonu ve tüm fakülte mezunlarının öğretmen olarak ataması yapılmıştır. (1) Yedek subay öğretmenler: 11 Ekim 1960 tarihli bir kanunla lise ve dengi okul mezunları ile üniversite ve yüksek okullardan mezun olmadan ayrılanlar bir kurstan geçirilmiş, askerliklerini köyde ilkokul öğretmeni olarak yapmış olanlardan isteyenler 26 Temmuz 1963 tarihli bir kanunla sürekli öğretmenliğe geçmişlerdir (Üstüner, 2004; Şendağ ve Gedik, 2015). (2) Vekil öğretmenler: 5 Ocak 1961 tarihli 222 sayılı İlköğretim ve Eğitim Kanunu ile ortaokul ve dengi okullardan mezun olanlardan 18 yaşını tamamlayanlar, bir kurstan geçirilerek ilkokullara atanmış; lise ve üstü mezunlar da yine bir kurstan geçirilerek orta dereceli okullara öğretmen olarak atanmışlardır (Üstüner, 2004). (3) Barış gönüllüleri: 1962 Eylülünden itibaren 1200'den fazla Amerikalı uzman, 70'li yıllara kadar Türkiye'ye gelerek gönüllü İngilizce öğretmenliği yapmışlardır. (4) Mektupla öğretmen yetiştirme: 1974'te tüm lise mezunlarına yüksek öğretim yaptırma vaat edilmiş, 46 bin kişi bu yolla öğretmen yetiştiren programlara alınmıştır. Resim, müzik, beden eğitimi dersleri de dâhil çeşitli alanlarda öğretmen yetiştirilmiştir. Bu kişiler yazları 5 hafta olmak üzere 3 yılda toplam 15 hafta öğretim yaparak öğretmen olmuşlardır (Üstüner, 2004; Baskan, Aydın ve Madden, 2006; Safran, 2014; Y1lmaz,2015; Gurbetoğlu, 2015; Tozlu, 2015; Önal, 2015). (5) Hızlandırılmış programla öğretmen yetiştirme: 1975’te siyasal ve ideolojik sebeplerden binlerce öğrenci öğrenimine devam edememiş, bu sebeple 1978'de hızlandırılmış programla öğretmen ihtiyacına çözüm yoluna gidilmiştir. Normal eğitim süresinin \%25-50'si kadar süre eğitim yapılmıştır. Uygulamalar ve seminer çalışmaları yapılmamıştır. Hızlandırılmış sistemle on binlerce genç, öğretmen olmuştur (Baskan, Aydın ve Madden, 2006; Gurbetoğlu, 2015; Önal, 2015; Safran, 2014; Tozlu, 2015; Üstüner, 2004). (6) Tüm fakülte ve yüksekokul mezunlarının öğretmen olması; Milli Eğitim Bakanlığı 1996'da tüm fakülte ve yüksekokul mezunlarından başvuranları öğretmen olarak atamıştır. On binlerce kişi hiçbir öğretmenlik formasyonu olmaksızın ve sınavsız mesleğe girmiştir (Tozlu, 2015). Bu sistemlerden en çok kullanılanı pedagojik formasyon yoluyla öğretmen yetiştirme olup, aşağıda ayrıntılı bir şekilde açıklanmıştır.

\section{Pedagojik Formasyon Eğitimi Yoluyla Öğretmen Yetiştirme}

Pedagoji kelimesi Fransızca pédagogie kelimesinden gelmekte olup "eğitim bilimi" anlamına gelmektedir. Formasyon kelimesi de Fransızca kökenli bir kelime olup; "biçimlenme, yetişim" anlamlarında kullanılmaktadır (TDK, 2016). Oxford sözlüğünde pedagoji özellikle akademik bir konu ya da teorik bir kavram olarak bir metot ya da uygulamanın öğretimi; formasyon ise "şekillendirme veya oluşturma süreci" olarak tanımlanmıştır. Pedagoji ve formasyon sözcüğü birleştirilirse "eğitim bilimsel biçimlendirme" denilebilir. Pedagojik formasyona, eğitim-öğretim verebilmek amacıyla sahip olunması gereken eğitim veya öğretmen olmak için bireylerin sahip olması gereken bir eğitim gözüyle bakılabilir (Y1lmaz, 2015). 1973 y1lında 1739 sayılı Milli Eğitim Temel Kanunu'nun yürürlüğe girmesiyle birlikte öğretmenlere yükseköğrenim görme zorunluluğu getirilmiştir (Bilir, 2011). 1970'lerden itibaren çeşitli fakültelerden mezun olanlar, öğretmen olmak için pedagojik formasyon almak zorundaydılar. 1997-1998 yılları yaz tatillerinde 40 işgünü formasyon eğitimini tamamlayanlar öğretmen olma sertifikası almışlar, 1998-1999'da tüm formasyonlar kaldırılmış, 2001'de tekrar açılmıştır (Yılmaz, 2015).

Milli Eğitim Bakanlığı 1980 yılında 21 kredilik öğretmenlik formasyonu programını uygulamaya koymuştur. 1990'larda ise 33 kredilik ilköğretim sınıf öğretmenliği sertifika programı geliştirilmiştir. $\mathrm{Bu}$ programdan mezun olan tüm fakülte mezunları öğretmen olarak eğitim sistemine girmiştir. 1995-1996 yıllarında öğretmen açığını kapatmak için üniversite mezunu olan her branştan genç, öğretmenlik formasyonu aranmaksızın, sınıf öğretmeni olarak atanmıştır (Bilir, 2011). 1998-1999'da eğitim fakültelerinin yeniden yapılandırılmaya başlaması ile birlikte; ilköğretim, yabanc1 diller, bilgisayar eğitimi, okul öncesi, beden eğitimi ve güzel sanatlar öğretmenleri 4 yıllık lisans programlarında yetiştirilmişlerdir. Ortaöğretimde ise (ortaöğretim fen ve matematik alanları ile ortaöğretim sosyal alanlar öğretmenliği) öğretmen yetiştirmek üzere iki yol benimsenmiştir. Bunların ilki, eğitim fakültesi lisans programına alınacak öğrencinin 3,5 yıl alan dersini ilgili fen-edebiyat fakültesinde okuması, sonra öğretmenlik formasyonu derslerini 1,5 yılda alarak yüksek lisanslı öğretmen olmasıdır. İkinci yol ise fen edebiyat mezunu bireylerin 
eğitim fakültelerinde öğretmenlik formasyonundan oluşan 1,5 y1llık tezsiz yüksek lisans programına devam ederek yüksek lisanslı öğretmen olarak mezun olmasıdır (Bilir, 2011; Kavcar, 2002; Polat, 2013; Sağlam, 2015; Taneri, 2016; Tozlu, 2015; Yıldırım ve Vural, 2014).

Aralık 2007'de YÖK fen-edebiyat fakültelerine pedagojik formasyon verme yetkisi vermiştir. 27 Ağustos 2009 tarihli toplantıda fen-edebiyat fakültelerinde okuyan öğrencilere lisans eğitimleri sırasında pedagojik formasyon alma hakkı verilmiştir. Bu kararla fen-edebiyat ve ilahiyat fakülteleri eğitim fakültelerine alternatif fakülteler haline gelmiştir (Bilir, 2011; Işık, Çiltaş ve Baş, 2010). YÖK, 28.01.2010 tarihinde almış olduğu kararla tezsiz yüksek lisans programını kaldırmış, yerine pedagojik formasyon sertifika programını getirmiştir. 2010-2011 y1lından itibaren hangi fakülte ya da bölümden mezun olunduğuna bakılmaksızın, isteyen öğrenci ya da mezun her bireyin bu eğitimi alabileceği belirtilmiştir (Polat, 2013; Tepeli ve Caner, 2014; Yıldırım ve Vural, 2014). Talim ve Terbiye Kurulu'nun 05.07.2012 tarih ve 97 sayılı kurul kararı ile ortaöğretim alan öğretmenliği tezsiz yüksek lisans ya da pedagojik formasyon programını tamamlamamış olanlar, Kamu Personeli Seçme Sınavında (KPSS) 75 ve daha yukarı puan aldıkları taktirde, pedagojik formasyon eğitimleri daha sonra yaptırılmak üzere alan öğretmenliklerine atanabilme, öğretmenliğe atananların pedagojik formasyon eğitimlerini ise adaylık dönemi içerisinde gerçekleştirecekleri belirtilmektedir (Talim ve Terbiye Kurulu, 2017).

Yüksek Öğretim Kurulunca izin verilen üniversitelerde yürütülen pedagojik formasyon programına 2013-2014 öğretim yılından itibaren ÖSYM tarafından yerleştirme yapılmasına karar vermiştir. Başvurularda Akademik Personel ve Lisansüstü Eğitimi Giriş Sınavı (ALES) sonuçlarının kullanılmasına karar vermiştir. Öğretmenlik sertifika programlarında ALES şartı konulmuştur. ALES sınavına girmeyenlerin formasyon programına başvurmaları için bir sonraki dönemde ALES sınavına katılmalarının gerekli olduğu belirtilmiştir (Yılmaz, 2015; Sağlam, 2015). 2014-2015 yıllarına bakıldığında ise pedagojik formasyon başvurusunda herhangi bir fakülteden mezun olmak kaydıyla öğrenci belgesi ya da diplomasıyla programlara kayıt olunabildiği görülmektedir (Yüksek Öğretim Kurulu, 2017).

Kısacası açıköğretim de dahil olmak üzere hangi fakülteden mezun olduğuna bakılmaksızın lisans mezunu olan tüm adaylar öğretmen olarak atanabilme şansına sahiptirler. Yılmaz (2015), 19732014 yı1ları arasında pedagojik formasyon eğitimi ile ilgili alınan kararların tarihsel sürecini sınıflandırmıştır. İlgili sınıflandırma Tablo 1'de verilmiştir.

Tablo 1. Pedagojik Formasyon Ile Öğretmen Yetiştirmenin Tarihsel Süreci

\begin{tabular}{|c|c|}
\hline Y11 & Yapılan Çalışma \\
\hline 1973 & $\begin{array}{l}1739 \text { sayılı Milli Ĕ̆itim temel kanunu ile öğretmenlere yüksek öğrenim görme } \\
\text { zorunluluğunun getirilmesi; } \\
\text { Diğer fakültelerin lisans mezunlarına öğretmenlik formasyonu alarak öğretmen olabilme } \\
\text { hakkı verilmesi }\end{array}$ \\
\hline 1974 & Mektupla öğretim ile 46.000 öğretmen atamasının yapılması. \\
\hline 1980 & 21 kredilik öğretmenlik formasyonunun verilmesi. \\
\hline 1982 & Öğretmen yetiştiren kurumların üniversitelere bağlanması. \\
\hline 1995-1996 & Herhangi bir lisans diplomasına sahip olanların sınıf öğretmeni olarak atanması \\
\hline 1998-1999 & Eğitim fakültelerinin yeniden yapılandırılması $(3,5+1,5$ ya da $4+1,5$ modelleri) \\
\hline 2007 & Fen-edebiyat fakültelerine pedagojik formasyon eğitimi hakkı verilmesi \\
\hline 2010 & $\begin{array}{l}\text { Fen-edebiyat fakültelerine öğretmen olmak için tanınan tezsiz yüksek lisans programlarının } \\
\text { kaldırılması, bunun yerine iki yarıyıllık pedagojik formasyon eğitiminin getirilmesi }\end{array}$ \\
\hline 2012 & Fen edebiyat fakültelerine yeni girecek öğrencilerden formasyon hakkının alınması \\
\hline 2013 & $\begin{array}{l}\text { Pedagojik formasyona devam edecek öğrencilerinin ÖSYM tarafından yerleştirilmesinin } \\
\text { yapılması (ALES şartı) }\end{array}$ \\
\hline 2014 & $\begin{array}{l}\text { Pedagojik formasyon eğitimi alma hakkının mezun olan, lisansa devam eden ve açık öğretim } \\
\text { öğrencilerine serbest bırakılması }\end{array}$ \\
\hline
\end{tabular}

Tablo 1'e göre 1973 ve 2014 yılları arası pedagojik formasyon öğrenci alımları ile ilgili esaslar incelendiğinde istikrarsızlık olduğu görülmektedir. Formasyonla öğretmen yetiştirme sisteminde 
sürekli ve düzenli olarak uygulanan bir yaklaşım olmadığı dikkati çekmektedir. Tabiki öğretmen yetiştirme politikasında yaşanan istikrarsızlıklar eğitimin kalitesini de etkilemektedir.

Alan yazın tarandığında pedagojik formasyon alan öğrencilerle ilgili bir takım araştırmalar yapıldığı görülmüş̧ür. Sağlam (2014) tarafından yapılan araştırmada pedagojik formasyon programının etkililiği araştırılmıştır. Araştırmaya katılan öğrencilerden çoğu programı etkili bulmuşlardır. Yürütülen programla ilgili en önemli sorun derslerine uzman öğretim üyelerinin girmemesi olmuştur. Diğer sorunlar ise derslerin zamanında başlamaması, duyuruların zamanında yapılmaması, yetkili birimlere ulaşılamaması yönündedir. Katılımcılar ayrıca lisans mezuniyeti sonrası katıldıkları programın hem maddi açıdan, hem de zaman sıkıntısı olması sebebiyle kendilerine göre sorun olduğunu ifade etmişlerdir. Ayrıca yapılan araştırmada katılımcılar bu programın lisans yıllarında verilmesinin daha etkili olacağını belirtmişlerdir. Taneri (2015) tarafından yapılan araştırmada pedagojik formasyon programının niteliği ile ilgili öğrencilerin görüşlerini almak amaçlanmıştır. Araştırmaya katılan pedagojik formasyon öğrencileri derslerin içeriğini yararlı ve ilginç bulduklarını belirtmişlerdir. Öğrencilerin en çok şikâyet ettiği konular arasında bazı öğretim elemanlarının yetişkin eğitimi konusunda yetersiz olması, öğretmenlik uygulaması derslerinin verimsiz olması, bina, araç-gereç ve alt yapının yetersiz olması yer almaktadir.

Kiraz ve Dursun (2015) pedagojik formasyon eğitimi alan öğretmen adaylarının aldıkları eğitime ilişkin algılarını araştırmışlardır. Katılımcılar bu eğitimi almanın öğretmen olmayı kolaylaştıracağını düşünmektedirler. Katılımcıların bir kısmı eğitimi yeterli ve geliştirici bulurken; diğer kısmı ise yetersiz ve gereksiz bulduklarını ifade etmişlerdir. Altınkurt, Yılmaz ve Erol (2014) tarafından yapılan araştırmada pedagojik formasyon programına devam eden öğrencilerin öğretmenlik mesleğine ilişkin motivasyonlarının yüksek olduğu, aldıkları eğitimin öğrencilerin öğretmenlik mesleğine yönelik tutumlarını olumlu yönde etkilediği yönünde bulgulara ulaşılmıştır. Kartal ve Afacan (2012) ise pedagojik formasyon öğrencilerinin öğretmenlik mesleğine yönelik tutumlarının orta düzeyde olduğunu tespit etmişlerdir. Öğretmen adaylarının yarıdan fazlası öğretmenlik mesleğine yönelik kendilerini yeterli bulmaktadırlar. Bağçeci, Yıldırım, Kara ve Keskinpalta (2015) tarafindan yapılan araştırmada pedagojik formasyon öğrencileri ile eğitim fakültesi öğrencilerinin öğretmenlik mesleğine yönelik tutumlarının karşılaştırılması amaçlanmıştır. Araştırmada formasyon eğitimi öğrencilerinin öğretmenlik mesleğine yönelik tutumları, eğitim fakültesi son sınıf öğrencilerinden daha olumlu olduğu yönünde bulgulara ulaşılmıştır. Görüldüğü gibi pedagojik formasyon eğitimi alan öğrencilerle ilgili yapılan araştırmalar mevcuttur. Fakat öğrencilerin kendilerinden kaynaklanan sorunlarına ilişkin, bu sorunların ortaya konulmasını hedefleyen bir araştırma yapılmadığı tespit edilmiştir. Öğrencilerin kendileri kaynaklı sorunlarını bilip, bunları çözme yoluna gitmesi öğrencilerin başarı düzeylerinin artmasında etkili olabilir. Yapılan bu araştırma pedagojik formasyon eğitimi alan öğrencilerin kendilerinden kaynaklanan sorunlarını tespit etmek amacıyla yapılmıştır. Bu genel amaçtan yola çıkarak pedagojik formasyon eğitimi alan öğrencilerin kendilerinden kaynaklanan ailevi, maddi, psikolojik, fizyolojik ve toplumsal sorunlarının neler olduğu sorularına yanıt aranmaya çalışılmıştır.

\section{Yöntem}

Araştırma mevcut olan durumu ortaya koyarak, açıklamak amacıyla yapıldığı için tarama modelindedir (Karasar, 1991). Tarama modeli araştırmalarda, araştırılan konu ile ilgili detaylı betimleme yapılmaktadır (Büyüköztürk, Çakmak, Akgün, Karadeniz ve Demirel, 2008). Derinlemesine ve ayrıntılı olarak çalışmaya olanak tanıması nedeniyle araştırmada nitel araştırma yaklaşımı kullanılmıştır (Patton, 2014). Yaşamda gerçekte var olan, kendi ortamındaki bir durumu araştırma ve betimleme yapma nedeniyle araştırma durum çalışmasıdır (Creswell, 2016). Durum çalışmasında bir veya birkaç durum tanımlanarak yorumlanmaktadır (Yıldırım ve Şimşek, 2006; Merriam, 2013). Bu araştırmada, gerçekte var olan durum pedagojik formasyon eğitimi alan öğrencilerin kendilerinden kaynaklanan sorunlarının olmasıdır. İlgili durum araştırılarak, ayrıntılı olarak ele alınmıştır. 


\section{Araştırmanın Çalışma Grubu}

Araştırmanın çalışma grubunu, 2016-2017 akademik yılı Aydın Adnan Menderes Üniversitesinde pedagojik formasyon eğitimi alan öğrenciler oluşturmaktadır. Araştırmaya 300 gönüllü pedagojik formasyon öğrencisi katılmıştır. Çalışma grubu amaçlı örnekleme yöntemi ile seçilmiştir. Amaçlı örnekleme yönteminin kullanılma nedeni katılımcıların araştırılan konuya hâkim olması düşüncesiyle, araştırmaya fayda getireceği düşüncesidir (Monette, Sullivan ve Dejong, 1990). Amaçlı örnekleme ile seçilen örneklemin de evreni temsil etmesi beklenmektedir (Tavşancıl ve Aslan, 2001). Araştırmada kolay ulaşılabilir durum örneklemesi kullanılmıştır. Bu, araştırmaya hız ve pratiklik kazandırması için, araştırmacıya yakın ve erişimi kolay olması sebebiyle tercih edilmiştir (Yıldırım ve Şimşek, 2006). Tablo 2'de çalışmaya katılan formasyon öğrencilerine ait kişisel bilgiler verilmiştir.

Tablo 2. Formasyon Öğrencilerine Ait Kişisel Bilgiler

\begin{tabular}{llllllllc}
\hline \multirow{2}{*}{$\begin{array}{c}\text { Formasyon } \\
\text { grubu }\end{array}$} & \multicolumn{9}{c}{ Değişkenler } \\
\cline { 2 - 10 } & \multicolumn{2}{c}{ Cinsiyet } & \multicolumn{7}{c}{ Yaş } & \multicolumn{2}{c}{ Çalışma durumu } \\
\cline { 2 - 9 } & $\mathrm{K}$ & $\mathrm{E}$ & $21-26$ & $27-32$ & $33-38$ & $39+$ & Çalışan & Çalışmayan \\
\hline Mezun grup & 54 & 62 & 30 & 72 & 65 & 3 & 70 & 100 \\
Okuyan grup & 124 & 60 & 130 & - & - & - & 27 & 103 \\
\hline Toplam & 178 & 122 & 160 & 72 & 65 & 3 & 97 & 203 \\
\hline
\end{tabular}

Tablo 2'ye göre araştırmaya katılan pedagojik formasyon öğrencilerinin 178'i kadın, 122'si erkek; 160 öğrenci 21-26 yaş aralığında, 72 öğrenci 27-32 yaş aralığında, 65 öğrenci 33-38 yaş aralığında ve 3 ögrenci 39 yaş ve üzerindedir. Araştırmaya katılan pedagojik formasyon öğrencilerinin 130'u son sınıf öğrencisi, 170'i herhangi bir lisans programından mezun durumdadır. Son sinıf öğrencilerinden 130 öğrenciden 27'si herhangi bir yerde çalışmaktadır, 103'ü sadece öğrencidir. Okuyan öğrenci grubunun tümü (130) bekârken; mezun grubunun 125'i evli, 65'i bekârdır. Araştırmaya katılan formasyon öğrencilerinin fakülte/yüksekokullara göre dağılımı Tablo 3'de verilmiştir.

Tablo 3. Formasyon Öğrencilerin Fakültelere/Yüksekokullara Göre Dağıllımı

\begin{tabular}{llll}
\hline Fakülte/yüksekokul & $\begin{array}{l}\text { Mezun } \\
\text { grup }\end{array}$ & Okuyan grup & Toplam \\
\hline Turizm & 42 & 75 & 117 \\
İktisadi ve İdari Bil. & 50 & 21 & 71 \\
Fen-Edebiyat & 47 & 20 & 67 \\
Hemşirelik-Sağllk & 22 & 10 & 32 \\
Bil. & & & \\
Beden Eğt. ve Spor & 6 & 4 & 10 \\
Diğer & 3 & - & 3 \\
\hline Toplam & 170 & 130 & 300 \\
\hline
\end{tabular}

Tablo 3'e göre araştırmaya katılan öğrencilerin 117'si Turizm, 71'i İktisadi ve İdari Bilimler, 67'si Fen-Edebiyat Fakültesinden, 32'si Hemşirelik Yüksekokulu ve Sağlık Bilimleri Fakültesinden, 10'u Beden Eğitimi ve Spor Yüksekokulundan, 3’ü ise diğer fakültelerden gelen öğrencilerdir. Mezun öğrenciler derslerini cumartesi ve Pazar günleri sabah 09.30 ila 23.30 arasında, okuyan öğrenciler derslerini hafta içi 17.30 ila 23.30 arasında yapmaktadırlar. Son sınıf öğrencileri Adnan Menderes Üniversitesinde farklı fakültelerde öğrenim gören öğrencilerdir. Mezun olan gruptan 170 öğrencinin 70’i herhangi bir yerde çalışırken; 100 mezun öğrenci işsizdir.

\section{Verilerin Toplanması, Analizi ve Araştırma Süreci}


Pedagojik formasyon öğrencilerinin kendilerinden kaynaklanan soruların tespit edilmesini amaçlayan bu araştırma için önce alan yazın taranmış, sonrasında araştırmacı tarafından bir form oluşturulmuştur. Formda pedagojik formasyon öğrencilerinin kendilerinden kaynaklanan sorunların neler olduğu sorulmuş ve öğrencilere formdaki soruları cevaplamaları için yeterli süre verilmiştir. Öğrencilerin cevaplama süreleri en düşük 20 dakika, en yüksek 45 dakika sürmüştür.

Araştırmada analizci/araştırmacı üçgenlemesi adı verilen teknik kullanılmıştır. Analizci üçgenlemesi iki ya da daha fazla kişinin nitel verileri analiz etmesi, bulguların karşılaştırılmasıdır. Bu çalışmada da farklı iki kişiye veriler analiz ettirilmiştir (Merriam, 2013; Patton, 2014; Creswell, 2016). Çalışmada katılımcıların görüşleri doğrudan alıntılar ile verilmiştir. Bu da geçerlik için önemlidir (Yıldırım ve Şimşek, 2006). Creswell (2016) araştırmayı yapan ve kodlayan uzmanların verileri farklı zamanlarda kodlaması ve kodlayıcılar arasındaki görüş birliğinin güvenirliği artıracağını ifade etmektedir. Bu sebeple güvenirliği hesaplamak için Miles ve Huberman (1994) formülünden yararlanılarak, görüş birliği hesaplanmıştır. $\mathrm{Bu}$ araştırma için görüş birliği \% 92 olarak hesaplanmıştır. Hall ve Houten (1983) ve Miles ve Huberman (1994) ölçütlerine göre bu araştırmadaki güvenirlik oranının yeterli olduğu görülmektedir. Araştırmadaki veriler içerik analizi yöntemi kullanılarak analiz edilmiştir. İçerik analizi yöntemi için temalar, kategoriler ve alt kategoriler belirlenmiştir (Yıldırım ve Şimşek, 2006; Creswell, 2016). Çalışma; ailevi, maddi, psikolojik, fiziksel ve sosyal sorunlar olarak beş temaya ayrılmıştır. Her tema katılımcıların vermiş oldukları cevaplar neticesinde kategori ve alt kategorilere ayrılmıştır. Araştırmada katılımcılara ait görüşler frekansla verilmiştir. Katılımcı görüşleri araştırmada değiştirilmeden, doğrudan alıntılarla verilmiş olup; her bir katılımcıya birer kod ile araştırmada sunulmuştur (Kadın: K, Erkek: E, Öğrenci: Ö, Mezun: M, 1-2-3...).

\section{Bulgular}

Araştırmanın bu bölümünde pedagojik formasyon öğrencilerinin sorunlarına yer verilmiştir. Öğrencilerin sorunları ailevi, maddi, psikolojik, fiziksel ve sosyal sorunlar olarak beş tema altında incelenmiştir. Ardından öğrencilerin görüşleri doğrultusunda sorunlara çözüm önerilerine yer verilmiştir.

\section{Öğrencilerin Ailevi Sorunlarına İlişkin Bulgular}

Katılımcıların vermiş oldukları cevaplar neticesinde, belirttikleri ailevi sorunlar Tablo 4'de verilmiştir.

Tablo 4. Öğrencilerin Ailevi Sorunlarına Ilişskin Frekans Dă̆ılımı

\begin{tabular}{|c|c|c|c|c|}
\hline Tema & Kategoriler & Alt kategoriler & Son sinıf (f) & Mezun (f) \\
\hline \multirow{8}{*}{ 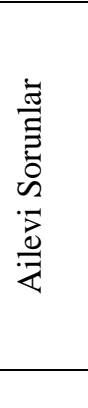 } & Ailenin & Bașına bir şey geleceği korku ve endişesi & 14 & 10 \\
\hline & olumsuz & Tartışma & 13 & 23 \\
\hline & tutumu & Ailenin formasyon eğitimini istememesi & 10 & 31 \\
\hline & & $\begin{array}{ll}\text { Toplam } \\
\end{array}$ & 37 & 64 \\
\hline & Aileye & Birlikte zaman geçirememe & 12 & 115 \\
\hline & $\begin{array}{l}\text { zaman } \\
\text { ayıramama }\end{array}$ & $\begin{array}{l}\text { Sabah erken gitmek, geç saatlerde dönmek, hafta } \\
\text { sonunun dolu olması ve sürekli derslerle meşgul } \\
\text { olma }\end{array}$ & 14 & 115 \\
\hline & & $\begin{array}{l}\text { Toplam } \\
\end{array}$ & 26 & 230 \\
\hline & & Genel Toplam & 63 & 294 \\
\hline
\end{tabular}

Tablo 4'e göre pedagojik formasyon öğrencilerinin ailevi sorunları iki kategoride incelenmiştir. Bunlar "ailenin olumsuz tutumu ile aileye zaman ayıramama" kategorileridir. İlk kategoride son sınıf öğrencileri 37 görüş bildirirken, mezun öğrenciler 64 görüş bildirmiştir. İkinci kategoride son sınıf öğrencileri 26 görüş bildirirken, mezun öğrenciler 230 görüş bildirmiştir. Son sinıf öğrencilerinin ailevi sorunlar temasında toplam 63 görüş bildirirlerken, mezun öğrenciler 294 görüş bildirmiştir. Mezun öğrenciler, lisans eğitimine devam eden formasyon öğrencilerine göre daha fazla ailevi sorun yaşamaktadırlar. Bunun sebebi mezun öğrencilerin büyük bir çoğunluğunun evli 
olması ve evli olmayanların da aileleriyle birlikte yaşıyor olması olarak açıklanabilir. Son sınıf öğrencilerinin büyük bir çoğunluğu ailelerinden uzakta olduğu için ailevi sorunları daha az yaşadıkları söylenebilir. Aşağıda katılımcı görüşlerine örnekler verilmiştir.

$>$ Formasyon eğitimi başladiğı günden beri, aileme tam olarak vakit ayıramıyorum. Hafta sonlarımız sabah 6'dan akşama kadar formasyonda ve yollarda geçiyor (M, E, 269).

$>$ Formasyon eğitiminin, geç saatte bitmesinden dolayı eve geç varmam nedeniyle ailem endişeleniyor $(\ddot{O}, K, 70)$.

$>$ Aile beklentileri her zaman yüksek. Bir çatışma her zaman oluşuyor. Eee üniversite bitirdin ne yapacaksın? Eee formasyon da aliyorsun, şimdi ögretmen olabilecek misin? Hep bir soru kipi olması sinir bozucu. Çalışlyorum, olursa olucam nasip, olmazsa intihar mı ediyim? diyorum. Karşıllklı bir çatı̧̧ma her zaman var ve bu evde gerginlik yaratıyor (M, K, 126).

$>$ Geç saatte çıtıtı̆̆ım için ailem endişeleniyor. Okulla birlikte yürütmeye çalıştı̆̆ım için derslerimde düşüs olacă̆ını düşünüyorlar (Ö, $K, 95)$.

> Bu yaştan sonra hala mı okul? diye eleştiriyorlar (M, E, 230).

$>$ Evli olmam, iki çocuğumun olması ve derslerin akşam olması sebebiyle ev yaşantımızda sorunlara sebep olabiliyor. Mesela kış döneminde çocuğumu okuldan almam mümkün olmuyor, çünkü aynı saatte dersim oluyor (M, E, 179).

\section{Öğrencilerin Maddi Sorunlarına İlişkin Bulgular}

Katılımcıların vermiş oldukları cevaplar neticesinde, belirttikleri maddi sorunlar Tablo 5'te verilmiştir.

Tablo 5. Öğrencilerin Maddi Sorunlarına Ilişkin Frekans Dă̆gllımı

\begin{tabular}{|c|c|c|c|c|}
\hline Tema & Kategoriler & Alt kategoriler & Son sinif (f) & Mezun (f) \\
\hline \multirow{10}{*}{ 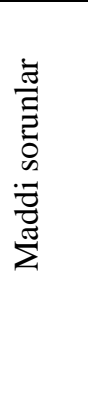 } & \multirow{3}{*}{$\begin{array}{l}\text { İşsizlik/sigortalı } \\
\text { işi olmama }\end{array}$} & İhtiyaçlarını karşılamakta sorun & 15 & 20 \\
\hline & & Aileyi/kendini geçindirmekte sorun & 27 & 10 \\
\hline & & Toplam & 42 & 30 \\
\hline & \multirow{7}{*}{ Parasal sikıntılar } & Formasyon ücreti & 35 & 170 \\
\hline & & Yol & 92 & 56 \\
\hline & & Yeme-içme & 30 & 71 \\
\hline & & Konaklama & 79 & 55 \\
\hline & & Kredi çekme & 4 & 10 \\
\hline & & Toplam & 240 & 362 \\
\hline & & Genel toplam & 282 & 392 \\
\hline
\end{tabular}

Tablo 5'e göre öğrencilerin maddi sorunları "işsizlik veya sigortalı işe sahip olmama ve parasal sıkıntılar" olarak iki kategoride incelenmiştir. Birinci kategoride son sınıf öğrencileri 42 görüş bildirirken, mezun öğrenciler 30 görüş bildirmiştir. İkinci kategoride son sınıf öğrencileri 240 görüş bildirirken, mezun öğrenciler 362 görüş bildirmiştir. Toplam sonuçlara bakıldığında son sınıf öğrencileri birinci kategoride 282 görüş bildirirken; mezun öğrenciler 392 görüş bildirmişlerdir. Bunun sebebi öğrencilerin parasal ihtiyaçlarını ailelerinin karşılaması, mezunlarınsa büyük bir çoğunluğunun kendilerinin karşılamaya çalışması olabilir. Aşağıda katılımcı görüşlerine örnekler verilmiştir.

> Formasyon ĕgitimi maddi açıdan biraz zorluk çekmemize neden oldu. Ücreti toparlamada zorlandık ama sonunda kredi çekerek hallettik (Ö, K, 76).

$>$ Çalışmayan bir birey olduğum için aileme maddi olarak külfetim. Bu konuda aileme karşı kendimi eksik hissediyorum (M, K, 100).

$>$ Maddi açıdan sorun yaşlyoruz. Yol masrafi, harç ücreti gibi sorunlar oluyor. Hem normal okulumun masrafi, hem formasyon eğitiminin masrafi bizi etkiliyor (Ö, $K, 11)$.

$>$ Ekonomik olarak kaynak bulmada sorun yaşlyorum. Aileme karşı mahcubum. Isteklerini karşılamakta zorlanıyorum (M, E, 244). 
$>$ Formasyon, için ödediğimiz miktarın fazla olması bir sorun. Üniversite için yaptı̆̆ımız harcamalara ekstra yük oluşturuyor. Ailemde üniversitede okuyan kardeşlerimin de olması maddi sorunlara neden oluyor $(\ddot{O}, K, 79)$.

$>$ Formasyon ĕgitimi alırken, ailemin ve benim en fazla karşılaştı̆̆ımız sorum maddi anlamda. Aydın'ın ilçesinden geldiğim için yol, yemek ve diğer ekstralar....Formasyon dişı başka harcamalarım da olduğu için sıkıntı yaşıyorum (M, K, 97).

\section{Öğrencilerin Psikolojik Sorunlarına İlişkin Bulgular}

Katılımcıların vermiş oldukları cevaplar neticesinde, belirttikleri psikolojik sorunlar Tablo 6' da verilmiştir.

Tablo 6. Öğrencilerin Psikolojik Sorunlarına Ilişkin Frekans Dă̆glımı

\begin{tabular}{|c|c|c|c|c|}
\hline Tema & Kategoriler & Alt kategoriler & Son sinif (f) & Mezun (f) \\
\hline \multirow{12}{*}{ 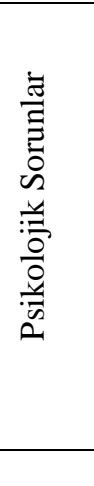 } & \multirow{6}{*}{ Stres } & Uyum sorunları & 50 & 41 \\
\hline & & Dersleri anlamama & 67 & 65 \\
\hline & & Kendini ait hissetmeme & 13 & 57 \\
\hline & & Ödevleri yetiştirememe & 86 & 54 \\
\hline & & Gerginlik ve sinirlilik & 76 & 42 \\
\hline & & Toplam & 292 & 259 \\
\hline & \multirow{6}{*}{ Korkular } & Formasyon alsa da işsiz kalacağı düşüncesi & 104 & 90 \\
\hline & & Gelecek kaygisı & 120 & 43 \\
\hline & & Derslerden kalma korkusu & 8 & 12 \\
\hline & & Dersleri/işleri sebebiyle başarısız olacağı korkusu & 34 & 11 \\
\hline & & $\begin{array}{l}\text { Toplam } \\
\end{array}$ & 266 & 166 \\
\hline & & Genel toplam & 558 & 415 \\
\hline
\end{tabular}

Tablo 6'ya göre psikolojik sorunlar stres ve korkular olarak iki kategoride incelenmiştir. Birinci kategoride son sınıf öğrencileri 292 görüş bildirirken, mezun öğrenciler 259 görüş bildirmiştir.İkinci kategoride son sınıf öğrencileri 266 görüş bildirirken, mezun öğrenciler 166 görüş bildirmiştir.Genele bakıldığında son sınıf ögrencileri 558 görüş bildirirken, mezun öğrenciler 415 görüş bildirmişlerdir. Aşağıda öğrenci görüşlerine yer verilmiştir.

$>$ Hem iş, hem formasyon beni yoruyor. Eve iş götürüyorum mecburen, ders çalışlyorum. Yoğun olduğum için stres yaşamama sebep oluyor (M, E, 259).

$>$ Ailemin beklentileri yüksek. Bitirince hemen öğretmenliğe başlayacă̆ım sanıyorlar. Bu beni psikolojik anlamda yoruyor (M, K, 176).

$>$ Derslerden kalacă̆ım düşüncesi beni yoruyor. Kalınca tekrar para ödeyeceğiz. Bu bende psikolojik baskl yaratıyor (Ö, $K, 93)$.

$>$ Aynı zamanda çalıştığım için stres ve yoğunluk durumumda artış var. Olumsuz ve depresif davranmama neden oluyor ( $M, E, 137)$.

$>B u$ eğitim alsam da ögretmen olamayacağım düşüncesi beni geriyor. Bizim branştan çok az aliniyor $(M, K, 131)$.

\section{Öğrencilerin Fizyolojik Sorunlarına İlişkin Bulgular}

Katılımcıların vermiş oldukları cevaplar neticesinde, belirttikleri fiziksel sorunlar Tablo 7'de verilmiştir.

Tablo 7. Öğrencilerin Fizyolojik Sorunlarına Ilişkin Frekans Dă̆ılımı

\begin{tabular}{|c|c|c|c|c|}
\hline Tema & Kategoriler & Alt kategoriler & Son sinif (f) & Mezun (f) \\
\hline \multirow{8}{*}{ 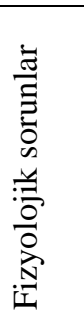 } & & Uykusuzluk & 14 & 31 \\
\hline & Psikosomatik & Baş ağrısı & 15 & 33 \\
\hline & rahatsızlıklar & Saç dökülmesi & 8 & 12 \\
\hline & & Mide problemleri & 21 & 4 \\
\hline & Toplam & & 58 & 80 \\
\hline & Bedensel & Kendini ihmal etme & 26 & 115 \\
\hline & sorunlar & Yorgunluk ve Halsizlik & 103 & 98 \\
\hline & & Dengesiz beslenme & 32 & 10 \\
\hline
\end{tabular}




\begin{tabular}{ccc}
\cline { 2 - 3 } Toplam & 161 & 223 \\
\hline Genel toplam & 219 & 303 \\
\hline
\end{tabular}

Tablo 7 incelendiğinde fizyolojik sorunlar "psikosomatik rahatsızlıklar ve bedensel sorunlar" olarak iki kategoride incelenmiştir. Birinci kategoride son sınıf öğrencileri 58 görüş bildirirken, mezun öğrenciler 120 görüş bildirmiştir. İkinci kategoride son sinıf öğrencileri 161 görür bildirirken, mezun öğrenciler 223 görüş bildirmiştir. Fizyolojik sorunların geneline bakıldığında son sınıf öğrencileri 219 görüş bildirirken; mezun öğrenciler 303 görüş bildirmiştir. Aşağıda öğrenci görüşlerine yer verilmiştir.

$>$ Hem kendimi, hem de ailemi ihmal ediyorum, yoruldum artık. Ödev yetiştirmekten yoruluyorum ( $M, E, 76)$.

$>$ Bu eğitime başladı̆̆ımdan beri bir sürü sıkıntı yaşıyorum. Mide krampları yaşıyorum, sınavlar üst üste geliyor, saçlarımda dökülüyor, geriliyorum (Ö, K, 90).

$>$ Hem okul dersleri, hem formasyon dersleri beni yordu. Uykusuzluk yaşlyorum, okulum uzayacak, formasyondan kalacă̆ım düşüncesi var. Başıma ă̆rılar giriyor (Ö, $K, 12)$.

$>$ Dengesiz besleniyorum, gece eve gidip yemek yiyorum, para harcamamak için gün içinde geçiştiriyorum ( $M, K, 74)$.

$>$ Maddi slkıntılarım, dersler, eve geç gitmem, eşimi ihmal etmem ben de gerginlik oluşturuyor (M, E, 56).

\section{Öğrencilerin Toplumsal Sorunlarına İlişkin Bulgular}

Katılımcıların vermiş oldukları cevaplar neticesinde, belirttikleri sosyal sorunlar Tablo 8'de verilmiştir.

Tablo 8. Öğrencilerin Toplumsal Sorunlarına Ilişkin Frekans Dă̆glımı

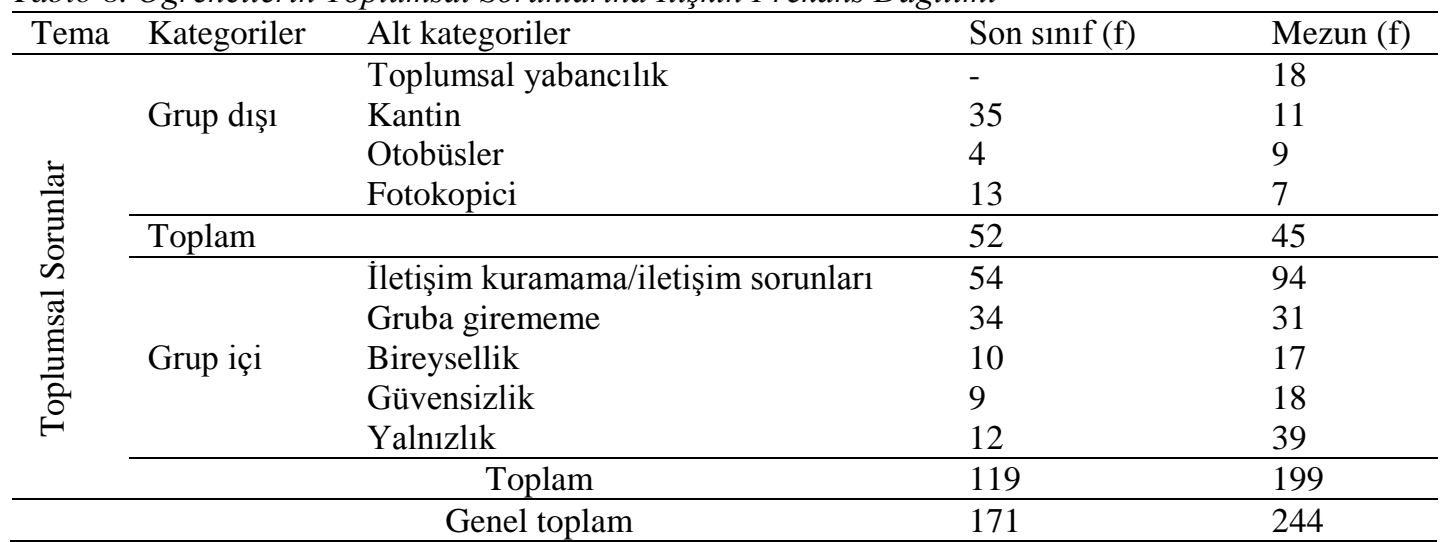

Tablo 8'e göre toplumsal sorunlar "grup dışı ve grup içi” olarak iki kategoride incelenmiştir. Birinci kategoride son sınıf öğrencileri 52 görüş bildirirlerken, mezun öğrenciler 45 görüş bildirmiştir. İkinci kategoride son sinıf öğrencileri 119 görüş bildirirken, mezun öğrenciler 199 görüş bildirmiştir. Toplumsal sorunların geneli incelendiğinde son sınıf öğrencileri 171 görüş bildirirken, mezun öğrenciler 244 görüş bildirmiştir. Aşağıda öğrenci görüşlerine yer verilmiştir.

$>$ Toplumda herkes kendi derdine düşmüş, çok fazla bireyselleşme var. Kimse kimsenin umrunda değil $(\ddot{O}, K, 145)$.

$>$ Güven sorunu yaşıyorum. Insanların birbirlerine yaklaşmalarından dolayı uzak duruyorum $(M, K, 2)$.

$>$ Insanlarla iletişim problemi yaşıyorum, onların beni anlamadığını düşünüyorum, kendimi yabancıymıs gibi hissediyorum (M, E, 34).

$>$ Şehir dışından otobüsle geliyorum, ulaşımımız çok kötü, zamanımın yarısı yolda geçiyor, bir de gecikenleri bekliyoruz (Ö, $K, 79)$.

$>$ Insanlar birbirine saygısız, herkes pimi çekilmiş bomba misali tartışma ve kavgaya hazır modda. Insanlar arasinda iletişim sıkıntısı var (Ö, E, 120). 
$>$ Bencillik, dışlanma, herkesin birbirini suçlaması, kimsenin kendini görmemesi vb. kendimi bu topluma ait hissetmiyorum $(M, K, 92)$.

\section{Tartışma ve Sonuç}

Alan yazın incelendiğinde pedagojik formasyon eğitimi alan öğrenciler ile ilgili bir takım araştırmaların (Altınkurt, Yılmaz ve Erol, 2014; Bağçeci, Yıldırım, Kara ve Keskinpalta, 2015; Kartal ve Afacan, 2012; Kiraz ve Dursun, 2015; Sağlam, 2014; Taneri, 2015) yapıldığ1 görülmektedir. Bunlardan sadece Sağlam'ın (2014) araştırmasında öğrenci sorunları, formasyon programının etkililiği araştırılmış ve program öğrencilerce etkili bulunmuştur. Sağlam'ın (2014) araştırmasında derslerin zamanında başlaması, duyuruların gerekli zamanlarda yapılmaması, derslerine giren ders hocalarının alanında yeterli uzmanlığa sahip olmaması gibi üniversite ve eğitim programı kaynaklı bir takım sorunlar da tespit edilmiştir. Bu açıdan yapılan araştırma ile farklılık göstermektedir. Sağlam’ın (2014) araştırmasında katılımcılar formasyon programını maddi sorun olarak gördüklerini ifade etmişlerdir. $\mathrm{Bu}$ yönüyle iki araştırma birbiriyle paralellik göstermektedir. Alan yazın taramaları neticesinde bu araştırmayla doğrudan benzerlik gösteren bir araştırma bulunamamıştır. Bu da araştırmayı diğer araştırmalardan farklı kılmaktadır.

Yapılan bu araştırmada, öğrencilerin kendilerinden kaynaklanan sorunları ailevi, maddi, psikolojik, fizyolojik ve toplumsal olmak üzere beş temada incelenmiştir. Araştırmaya katılan öğrencilerin geneline bakıldığında en çok psikolojik sorunların yaşandığı; en az ise ailevi sorunların yaşandığı tespit edilmiştir. Son sınıf öğrencileri en çok psikolojik sorunlar yaşarken; en az ailevi sorunlar yaşamaktadırlar. Mezun öğrenciler en çok psikolojik sorunlar yaşarken; en az toplumsal sorunlar yaşamaktadırlar. En çok sorun yaşayan grup mezun grubudur. Bunun nedeni mezun grupta yer alan öğrencilerin büyük bir kısmının evli olması, evli olan öğrencilerin, evlilik hayatının gerektirdiği anne-baba, eş olma gibi bir takım sorumluluklarının olması durumu olabilir. Aileye yeterli zaman ayırarmama, ilgilenmeme, zaman geçirememe, öğrencilik yaşamından uzaklaşmış olmanın verdiği psikolojik sorunlar, bunun yanı sıra yeni girilen topluma uyum sorunları, yeme, içme, barınma, yol paras1, formasyon ücreti gibi artan maddi sıkıntılar, stresli bir yaşam formasyon öğrencilerini etkilemektedir. Oysa okuyan grubunda olan öğrencilerin, sadece öğrenci olmaları sebebi ile ailevi sorunları alt düzeyde yaşadıkları, aynı şehirde ve aynı üniversitede eğitim almaları sebebiyle toplumsal sorunlarının çok az olması, ev geçindirme gibi bir sorumluluklarının olmaması, ailelerinden gelen parayı harcamaları nedeniyle maddi açıdan daha az sıkıntı yaşamaları olağandır. Öğrencilerin sorunlarının ortaya konulması onların öğrencilik yaşantılarının daha iyi bir şekilde geçmesini sağlayabilir. Öğrencilerin yaşamış oldukları psikolojik sorunları çözmek için üniversite bünyesinde verilen danışmanlık hizmetleri yaygınlaştırılarak, öğrencilerin psikolojik ve toplumsal sorunlarını en aza indirmek için kaygı, iletişim, stres yönetimi vb. gibi konularda öğrenci merkezli seminerler verilebilir. Formasyon öğretiminin öğrencilerin lisans öğrenimi sırasında verilmesi ile öğrencilerin daha az sorun yaşamaları sağlanabilir. Bu araştırma farklı üniversitelerde yapılarak sonuçlar karşılaştırılabilir. Aynı araştırma lisans öğrencilerine de uygulanarak onların da kendilerinden kaynaklanan sorunlar ortaya çıkarılabilir.

\section{Kaynakça}

Akyüz, Y. (2015). Türk Ĕgitim Tarihi. Ankara: PegemAkademi.

Altınkurt, Y.; Yılmaz, K. ve Erol, E. (2014). Pedagojik formasyon programı öğrencilerinin öğretmenlik mesleğine yönelik motivasyonları. Trakya Üniversitesi Eğitim Fakültesi Dergisi. 4(1), 48-62.

Argün, Z. (2008). Lise Matematik öğretmenlerin yetiştirilmesinde mevcut yargılar, yeni fikirler. TUBAV Bilim Dergisi. 1(2), 88-94.

Ayas, A. (2009). Öğretmenlik mesleğinin önemi ve öğretmen yetiştirmede güncel sorunlar. İnönü Üniversitesi Ĕ̈itim Fakültesi Dergisi. 10(3), 1-11.

Aycan, Ş. (2015). Liselere öğretmen yetiştirmede geri adım: yüksek öğretmen okullarından pedagojik formasyon kurslarına. MSKU Ĕ̈itim Fakültesi Dergisi. 2 (2), 61-72. 
Aydın, A. (1998). Eğitim fakültelerinin yeniden yapılandırılması ve öğretmen yetiştirme sorunu. Kuram ve Uygulamada Ĕ̈itim Yönetimi Dergisi. 4(3), 1-9.

Bağçeci, B., Yıldırım,i.; Kara, K. ve Keskinpalta, D.(2015). Pedagojik formasyon ve eğitim fakültesi öğrencilerinin öğretmenlik mesleğine yönelik tutumlarının karşılaştırılması. Erzincan Üniversitesi Eğitim Fakültesi Dergisi. 17(1), 307-324.

Başaran, İ. E. (1996). Türkiye Ĕ̈itim Sistemi. Ankara: Yargıcı Matbaası.

Baskan, G. A., Aydın, A. ve Madden, T. (2006). Türkiye'deki öğretmen yetiştirme sistemine karşılaştırmalı bir bakış. Ç.Ü. Sosyal Bilimler Enstitüsü Dergisi. 15(1), 35-42.

Baskan, G. A. (2001). Öğretmenlik mesleği ve öğretmen yetiştirmede yeniden yapılanma. Hacettepe Üniversitesi Eğitim Fakültesi Dergisi. 20, 16-25.

Bilir, A. (2011). Türkiyede öğretmen yetiştirmenin tarihsel evrimi ve istihdam politikaları. Ankara Üniversitesi Ë̆itim Bilimleri Fakültesi Dergisi. 44 (2), 223-246.

Büyüköztürk, Ş., Çakmak, E. K., Akgün, Ö. A., Karadeniz, Ş. and Demirel, F. (2008). Bilimsel Araştırma Yöntemleri. Ankara: Pegem Akademi.

Cambridge Sözlüğü. (2016). http://dictionary.cambridge.org adresinden 11.01.2017 tarihinde indirilmiştir.

Creswell, J. W. (2016). Nitel Araştırma Yöntemleri Beş Yaklaşıma Göre Nitel Araştırma ve Araştırma Deseni. (Edt. M. Bütün and S. B. Demir). Ankara: Siyasal Kitabevi.

Eşme, İ. (1999). Bugünün öğretmen yetiştirme modeli: sorunlar ve çözüm önerileri. M.Ü. Atatürk Eğitim Fakültesi Eğitim Bilimleri Dergisi. 11, 141-152.

Gurbetoğlu, A. (2015). Tanzimat'tan günümüze Türkiye'de öğretmen yetiştirme çabaları ve geçmişten alınmayan dersler. TYB Akademi Dil Edebiyat ve Sosyal Bilimler Dergisi. 5 (13), 75-94.

Işık, A. , Çiltaş, A. ve Baş, F. (2010). Öğretmen yetiştirme ve öğretmenlik mesleği. Atatürk Üniversitesi Sosyal Bilimler Enstitüsü Dergisi. 14(1), 53-62.

Hall, R. V. ve Houten, R. V. (1983). Managing Behavior, Behavior Modification: The Measurement of Behavior. Austin: Pro-ed.

Kartal, T. ve Afacan, Ö. (2012). Pedagojik formasyon eğitimi alan öğretmen adaylarının öğretmenlik mesleğine ilişkin tutumlarının incelenmesi. Mehmet Akif Ersoy Üniversitesi Eğitim Fakültesi Dergisi. 12 (24), 76-96.

Kavcar, C. (2002). Cumhuriyet döneminde dal öğretmeni yetiştirme. Ankara Üniversitesi Eğitim Bilimleri Fakültesi Dergisi. 35 (1-2), 1-14.

Kiraz, Z. ve Dursun,F. (2015).Pedagojik formasyon eğitimi alan öğretmen adaylarının aldıkları eğitime ilişkin algıları. Mersin Üniversitesi Eğitim Fakültesi Dergisi. 11(3), 1008-1028.

Karasar, N. (1991). Bilimsel Araştırma Yöntemi. Ankara: Nobel Yayınları.

Merriam, S. B. (2013). Nitel Araştırma Desen ve Uygulama İçin Bir Rehber. (Ed. S. Turan). Ankara: Nobel Yayın.

Miles, M. B. ve Huberman, A. M. (1994). Qualitative Data Analysis. Thousand Oaks, Sage.

Monette, D. R., Sullivan, T. J. ve Dejong, C. R. (1990). Applied Social Research. NewYork: Harcourt Inc.

Önal, M. (2015). Fen/edebiyat ve eğitim fakültelerinin geleceği ya da Türkiye'de bilim adamı ve öğretmen yetiştirme meselesi. TYB Akademi Dil Edebiyat ve Sosyal Bilimler Dergisi. 5 (13), 201-220.

Patton, M. Q. (2014). Nitel Araştırma ve Değerlendirme Yöntemleri. (Ed. M. Bütün ve S. B. Demir). Ankara: PegemAkademi

Polat, S. (2013). Pedagojik formasyon sertifika programı ve eğitim fakültesi öğrencilerinin öğretmenlik mesleğine yönelik tutumlarının incelenmesi. e-Uluslararası Eğitim Araştırmaları Dergisi. 4 (2), 48-60.

Safran, M. (2014). Eğitim fakülteleri, öğretmen yetiştirme süreci ve yeni arayışlar. IV. Öğretmen Yetiştirme Politika ve Sorunları Uluslar Arası Sempozyumu Bildiriler Kitabı. 15- 16 Mayıs 2014 Hacettepe Üniversitesi, Ankara Türkiye. 
Sağlam, A. Ç. (2015). Pedagojik formasyon sertifikası programının etkililiğinin öğrenci görüşlerine göre değerlendirilmesi. Klrıkkale Üniversitesi Sosyal Bilimler Dergisi. 5 (2), 64- 73.

Şendağ, S. ve Gedik, N. (2015). Yükseköğretim dönüşümünün eşiğinde Türkiye'de öğretmen yetiştirme sorunları: bir model önerisi. Eğitim Teknolojisi Kuram ve Uygulama. 5 (1), $72-$ 91.

Talim ve Terbiye Kurulu. http://ttkb.meb.gov.tr/www/80-sayili-karar/icerik/19 adresinden 15.02.2017 tarihinde indirilmiştir.

Taneri, P. O. (2016). Öğretmen adaylarının pedagojik formasyon sertifika programının niteliği hakkındaki görüşleri (Çankırı ili örneği). Kastamonu Ĕ̈itim Dergisi. 24 (3), 997-1014.

Tavşancıl, E. ve Aslan, E. (2001). İçerik Analizi ve Uygulama Örnekleri. İstanbul: Epsilon.

Tekışık, H. H. (1987). Türkiye'de öğretmenlik mesleği ve sorunları. Hacettepe üniversitesi Ĕgitim Fakültesi Dergisi. 24-33.

Tepeli, Y. ve Caner, M. (2014). Pedagojik formasyon programı öğrencilerinin öğretmenlik uygulaması ile ilgili görüşleri. Eğitim Bilimleri Araştırmaları Dergisi. 4(2), 313-328.

Tozlu, N. (2015). Öğretmen Yetiştirme üzerine düşünceler. TYB Akademi Dil Edebiyat Ve Sosyal Bilimler Dergisi. 5 (13), 123-135.

Türk Dil Kurumu Sözlüğü. (2016). http://www.tdk.gov.tr/,

Uygun, S. (2010). Türkiye'de öğretmen adaylarının seçimi ile ilgili bazı uygulamaların tarihsel analizi. Gazi Üniversitesi Ĕ̈itim Fakültesi Dergisi. 30 (3), 707-730.

Üstüner, M. (2004). Geçmişten günümüze Türk eğitim sisteminde ögretmen yetiştirme ve günümüz sorunlart. www.academia.edu adresinden 10.04.2017 tarihinde indirilmiştir.

Yıldırım, İ. ve Vural, Ö. F. (2014). Türkiye'de öğretrmen yetiştirme ve pedagojik formasyon sorunu. Journal of Teacher Education and Educators. 3 (1), 73-90.

Yıldırım, A. ve Şimşek, H. (2005). Sosyal Bilimlerde Nitel Araştırma Yöntemleri. Ankara: Seçkin. Yüksek Ögretim Kurulu www.yok.gov.tr adresinden 17.01.2017 tarihinde indirilmiştir. 